\title{
GENDER PERSPECTIVE AND NEWMAN'S THEORY IN ERROR ANALYSIS OF STUDENTS' ANSWERS IN RATIO AND PROPORTION
}

\author{
Nida Fathiya Hanifah ${ }^{1}$, Wahyu Hidayat ${ }^{2}$, Usman Aripin ${ }^{3}$ \\ ${ }^{1}$ IKIP Siliwangi, Jl. Terusan Jenderal Sudirman, Cimahi, Indonesia. \\ nidnfhani@gmail.com \\ ${ }^{2}$ IKIP Siliwangi, Jl. Terusan Jenderal Sudirman, Cimahi, Indonesia. \\ wahyu@ikipsiliwangi.ac.id \\ ${ }^{3}$ IKIP Siliwangi, J1. Terusan Jenderal Sudirman, Cimahi, Indonesia. \\ usman.aripin@ikipsiliwangi.ac.id
}

\begin{abstract}
This research was conducted to find out how the gender perspective affects the mistakes made by students in the ratio and proportion questions. Mindset's differences between male and female will affect how they solve problems and it will also affect their mathematics learning outcomes. Errors made by students were analyzed using the Newman error analysis indicator. Error analysis indicators used are reading errors, misunderstanding errors, transformation errors, process errors, and error writing answers (encoding). This research uses descriptive qualitative research method. This research was conducted at SMPN 2 Cimahi. The instruments in this study were test and non-test questions. It can be concluded from this research that there are differences between male and female students when working on ratio and proportion concept questions based on the mistakes they've made. The most common mistakes made by male students are mistakes in the process of writing answers. This error occurs because they do not write down the complete answer details, it's because male tend to be simpler in solving problems. The most common mistake made by female is an error in understanding. It's because female tend to use logic-less when understanding the mathematical problems presented in the questions.
\end{abstract}

\begin{tabular}{lll}
\hline \multicolumn{1}{c}{ ARTICLE INFORMATION } \\
\hline Keywords & & Article History \\
$\begin{array}{l}\text { Newman error analysis } \\
\text { Ratio and proportion } \\
\text { Gender }\end{array}$ & & $\begin{array}{l}\text { Submitted Apr 27, 2020 } \\
\text { Revised Jul 18, 2020 } \\
\text { Accepted Jul 18, 2020 }\end{array}$ \\
\cline { 1 - 1 } Corresponding Author & \\
\hline
\end{tabular}

Nida Fathiya Hanifah

IKIP Siliwangi

Jl. Terusan Jenderal Sudirman, Cimahi, Indonesia.

Email: nidnfhani@gmail.com

\section{How to Cite}

Hanifah, N.F., Hidayat, W., \& Aripin, U. (2020). Gender Perspective and Newman's Theory in Error Analysis of Students' Answers in Ratio and Proportion. Kalamatika: Jurnal Pendidikan Matematika, 5(2), 103-118. 


\section{INTRODUCTION}

Mathematics is important to be learnt at least by all parties. That is because mathematics cannot be separated from our daily lives. Novtiar and Aripin (2017) state that mathematics is a daily activity which means that every day, every human activity uses mathematics according to their individual needs. According to Ruseffendi (Sari \& Aripin, 2018) mathematics is also the queen of science. It means that mathematics is used in almost all fields of science but does not depend on other sciences. The importance of mathematics is also seen from how mathematics is learnt at all levels of education in Indonesia, namely in primary, secondary, and higher education. It is based on the opinion of Resilona, Hidayat, \& Hendriana (2018) which states that every level of education learns mathematics because mathematics can increase the power of human thought. Also, Hidayat (2017) said that mathematics is one way of forming students 'mindset that can be measured by students' abilities.

One of the concepts in mathematics is ratio and proportion. In this concept, students learn how to equate two or more things in the lowest or simplest value, and determine the connection between the two things whether the proportion is direct proportion or inverse proportion. Problems that related to the concept of ratio and proportion are very easy to find in daily lives. As in the market, the concept of ratio and proportion is used to find out the difference between prices and quantities of goods, and also when we travel, for example, a scale which is one of the uses of the concept of direct proportion that can be found when using maps both digital maps and conventional maps.

The concept of ratio and proportion is one of the concepts that students need to understand. That is because the concept of ratio and proportion is a basic concept that will be used in advanced concepts such as the concept of social arithmetic and the concept of trigonometry. Utari, Ilma, Putri, \& Hartono (2015) states that ratio and proportion is one of the bases for learning mathematics, science and is useful in real life as well as various situations in daily lives. So when the students do not understand the concept of ratio and proportion, it will affect students' understanding of the next concept.

According to the importance of the concept of ratio and proportion, ideally students should be able to understand the concept of ratio and proportion well. But in reality, there are still many students who do not understand the concept of ratio and proportion well. Like the 
recognition of students in reality who claimed that he did not understand how to solve the ratio and proportion concept questions that had been modified. Also, according to the research of Rahmasantika \& Prahmana (2019) students have difficulty working on questions that are different from the ones exemplified by the teacher or non-routine questions. This can be affected by various factors. One of these factors is students 'abilities such as self-regulated learning and students' mathematical reasoning skill which, according to Zannati, Fitrianna, \& Rohaeti, (2018) have a strong effect on understanding ratio and proportion concepts.

Another thing that also affects the understanding of the concept of ratio and proportion is the selection of approaches and models in the learning process. as the results of research by Respati \& Gusrayani (2016) which shows that classes given an approach other than conventional approaches show a significant increase in the ratio and proportion concept.

However, in those studies the focus discussed is only limited to how to improve student learning outcomes in general, giving rise to the perception that the learning outcomes of male and female students are the same. Though learning outcomes will be influenced by one's mindset and there are differences in the mindset of female and male students. Nur \& Palobo (2018) states that gender differences can be a factor that distinguishes the way someone thinks. Besides, Dilla, Hidayat, \& Rohaeti (2018) research also shows that gender differences affect the results of students' mathematical creative thinking abilities.

Basically, Male tend to use logic more than female. So that male students more easily use logic to understand the problems presented. But male rarely can multitask and tend to refuse if they are required to memorize the rules in the concept because male's souls are free spirits. As a result, male students often use their logic and ignore the rules learned when solving problems. In line with the opinion of Videbeck (Apriady, Yanis, \& Yulistini, 2016) which states that male are more accustomed to facing problems while female are not.

While female do something, they are more likely to use their feelings and they are often fixated on the rules that apply. So this situation makes it difficult for female to understand the modified problem and match the rules that are understood to solve the problem. According to Purnawati, Paidi, \& Hidayati, (2016) psychologically female rely more on their feelings in acting. Consequently, this can affect the way of thinking of each student and it will also affect the way they solve the problem presented in the questions.

To find out the ability of students in the ratio and proportion concept can be done in 
several ways, one of them is by analyzing the mistakes or errors made by students while working on questions about the ratio and proportion concept. There are various types of mistakes that can be made in solving a problem, one of which is the type of error raised by Newman. Newman (Amalia, 2017) argues that errors that occur specifically in working on questions in the form of story questions are divided into 5 namely reading errors, misunderstanding errors, transformation errors, process errors, and error writing answers (encoding).

Based on background, this research is important to be able to be a proof of differences between male and female students in solving problems. Thus, the results of this study are expected to be considered in the preparation of lesson plans in class. Therefore the research aims to find out more about student errors viewed from a gender perspective and Newman error analysis. This research is expected to provide new treasures in the world of education, especially mathematics education.

\section{METHOD}

This study used descriptive qualitative method. The study was conducted at SMPN 2 Cimahi. The subjects in this study were 36 students who had previously studied the concept of ratio and proportion.

The instrument of this research uses 5 test questions in the form of story questions on ratio and proportion concept. Data collection techniques in addition to the test, observation, and interviews were also carried out. Before being tested, test questions must first be tested by the content validity by experts so that it can be ascertained that the questions made are under the grid on the ratio and proportion concept.

After the test, it results are observed based on gender and errors from the standpoint of Newman's theory, namely 1) reading errors is errors caused by student errors in reading information from the questions, 2) misunderstanding is errors caused by students who are wrong in understanding the problem in the questions, 3) transformation errors is errors caused by students who are wrong in transforming information in a problem into a mathematical form in solving problems, 4) process errors is errors that occur due to errors in the answer process, such as arithmetic errors, and 5) errors writing answers is errors that occur due to incomplete answers written by students. Newman theory is used because Newman differentiate the types of errors based on the situations experienced by students. Then interviews were conducted to 
triangulate data to match test results with students' views.

\section{RESULT AND DISCUSSION}

After testing 36 students with 22 male students and 14 female students, the test results were examined and classified according to the type of error.

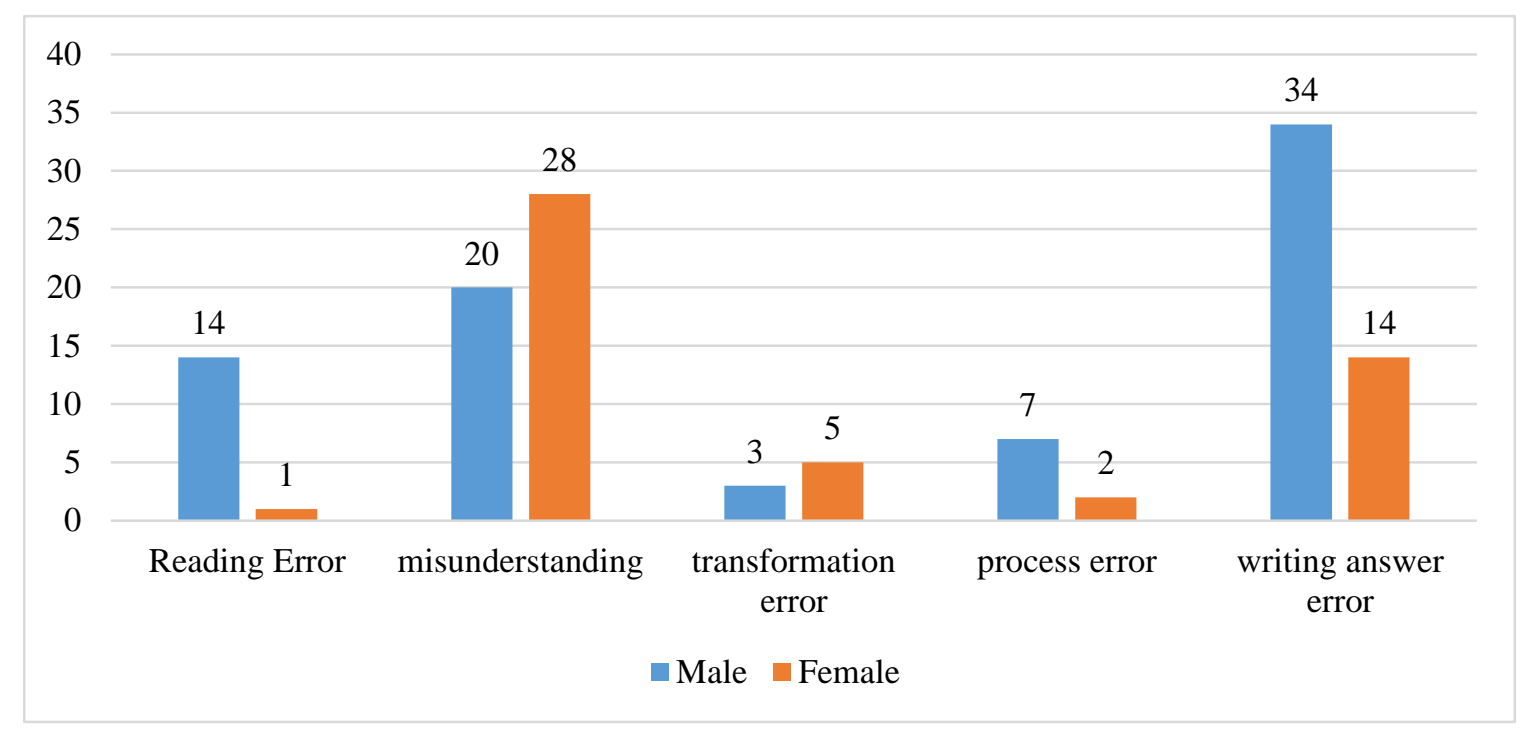

Figure 1. Data Errors Made By the Students

In figure 1, it appears that the most mistakes made by all students are mistakes in writing answers that are 48 mistakes. Mistakes in writing answers were also the most mistakes made by male students, 34 times. Whereas for female students the most common type of mistake made is a misunderstanding.

Errors in writing answers are mostly made by male students in question number 1 and question number 4 . In question number 1 students are asked to determine the ratio of cake ingredients. Mistakes in writing answers will certainly make the subject not get perfect points. Mistakes made include not writing down any information that is known from the question. Besides known information, some students also did not write the conclusions of the answers. This is certainly different from what is expected, where students can write answers completely.

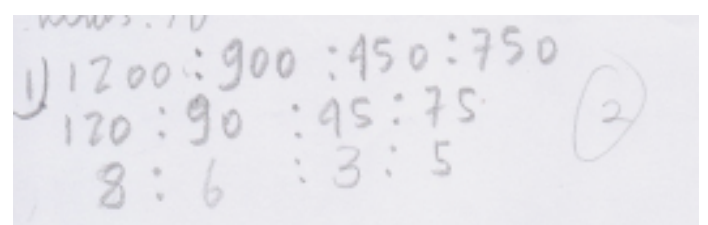

Figure 2. Number 1 By One of the Male Students 
Subjects with male gender are represented by L1. L1 made a mistake in writing the answer by not writing what is known and what the conclusion is from the answer. It can be seen from Figure 2 that L1 just wrote down the answer directly. Based on interviews, L1 did not include what was known and the conclusions answered because the subject wanted to solve the problem quickly and he felt no need to write down what was known and the conclusion. This is in line with the results of Krutetzki's research (Kholishoh, Pramudya, \& Kurniawati, 2017) which states that male tend to be less thorough, in a hurry, and get things done quickly.

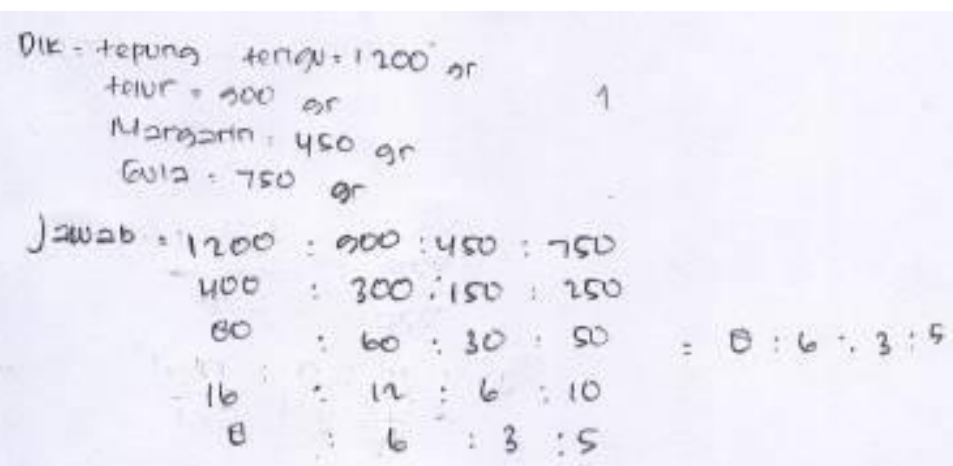

Figure 3. Number 1 By One of the Female Student

In the case of female students, almost all of them made the same mistake. Although they write information that is known from the problem, but they do not write the conclusions of the answers as seen in figure 3. It was found from interview that the subject was accustomed to writing answers like that. That means the subject is not accustomed to writing conclusions from each of the results of their answers.

Mistakes in writing answers become the most mistakes made by male students, the results of tests and interviews indicate that male students in working on problems do not want to be too bothered and write answers simply and not protracted. As a result of writing answers, even though the students' answers are correct but mistakes will reduce the points earned by students. While female write down overall what is known, but female follow what is usually taught to them. So, they don't write down conclusions because they're not used to it. This is following the research of Purwanto, Sukestiyarno, \& Junaedi (2019) which shows that male tend to make things simple while female have the stereotypical nature of being obedient, which makes them follow well what is taught to them.

The next type of error is an error in understanding the problem presented in the question. This mistake is the most mistakes made by female students. Even though many male 
students make this mistake to. The most misunderstanding is done in question number 2 and problem number 3 .

The question number 2 requires students to analyze the intent of the problem so that there is no misunderstanding that makes them fooled while working on the problem. While in question number 3 students are required to be able to understand the instructions contained in the picture that is presented as additional information to solve the problem.

In question number 2, all subjects, both male and female, did not get full points. even some students don't write down answers at all. But male students give more efforts to solve the problems. It can be influenced by the confidence of male who tend to be higher than female. In line with the opinion of the American Psychological Association (Yazidah, 2017) which states that male have more confidence than female in mathematics.

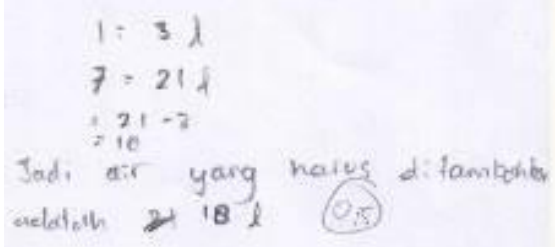

Figure 4. Answer Number 2 By One the Male Students

L2 writes the wrong answer, however from the answer in figure 4, it appears that L2 understands the direct proportion concept. When the subject was asked why the number of liters of water became 21 liters, L2 said that because in the problem, the ratio of water changes was from 1 to 7 , because the amount of water before being added was 3 liters to 7 then the 3 liters were multiplied by 7 so that it produced 21 liters. The L2 subject used its logic well, but L2 did not notice that in the problem, the amount of fruit mixed would affect the overall amount of the liquid. This is in line with the opinion of Kuretetzkii (Novitasari, 2017) which states that male are superior in logical reasoning.

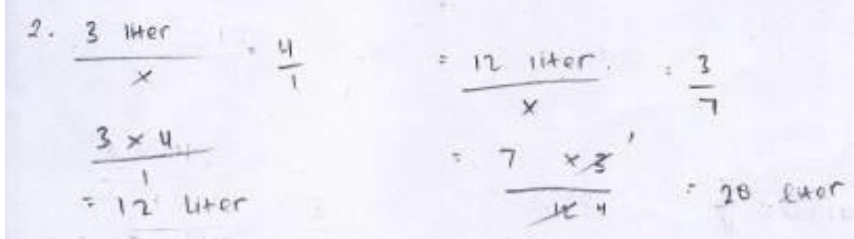

Figure 5. Answer Number 2 By One of The Female Students

For female subjects, as seen in figure 5, the one who wrote the completion step was P2 even though P2 still made mistakes. P2 compares the ratio of water along with the total 
amount of liquid. When asked why she wrote it like that, students answered "I don't know miss, I'm confused about how to solve this. Alright, I'll just multiply it”. It shows that P2 does not understand the problem and P2 also does not understand the concept of ratio and proportion. Therefore, an error in understanding made by $\mathrm{P} 2$ causes a transformation error, an operation error, and an error writing the answers.

Besides question number 2, the students also made a mistake in understanding problem-solving number 3. Male and female students also made a mistake in understanding problem number 3. In question number 3 the male student made a mistake by adding up all the nutritional content in the information in the picture, while the question only asked to calculate the protein intake for Putri's body as seen in figure 6.

$$
\text { 3. } \begin{aligned}
24+50+490 & =\frac{564 \mathrm{mg}}{2}=282 \mathrm{mg} \cdot 80.000 \mathrm{mg} \\
& =20.000-282=79.718 \mathrm{mg}
\end{aligned}
$$

Figure 6. Answer of Number 3 By One of The Male Students.

The subject also did not write down the ratio and only wrote down the amount of nutrition that had entered Putri's body. For female students as seen in figure 7 , one of the misconceptions made in question number 3 was the subject comparing the amount of protein found in 1 milk box with the daily nutritional adequacy rate, while the question asked for a ratio between the amount of protein that had entered Putri's body and the amount of Putri's protein needs when she is sick. It shows that the female students did not understand the meaning of the problem well.

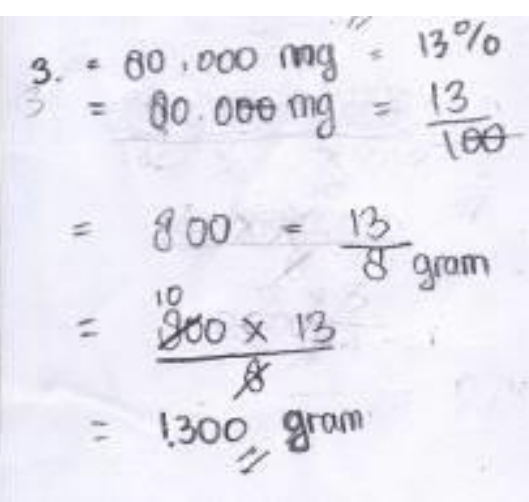

Figure 7. An Answer of Number 3 by One of The Female Students 
For errors in understanding, this error occurs due to the subject both female and male do not understand the problem presented. This is in line with Amalia's (2017) research which states that errors in solving problems can occur one of the reasons is because the students cannot understand the questions well. Besides that from question number 2, it can be seen that male try more to write down the answers even though the answers are not quite right, but only a few female write the answers. This is following the opinion of Purwanto et al., (2019) which states that one of the stereotype traits of male is ambitious. That causes that male are more challenged to solve the problem.

The next mistake made by the students was reading errors, this error was made 15 times, including 14 times by male students and once by female students. This reading error makes students get incorrect answers. it happened because there was a mistake when collecting information from the questions. This reading error occurred in question number 3 , mostly male students, careless when reading nutritional information in the picture. This is in line with the research of Ishak \& Irmayanti (2018) which shows that male students are less thorough in working on problems so that they get the wrong answer.

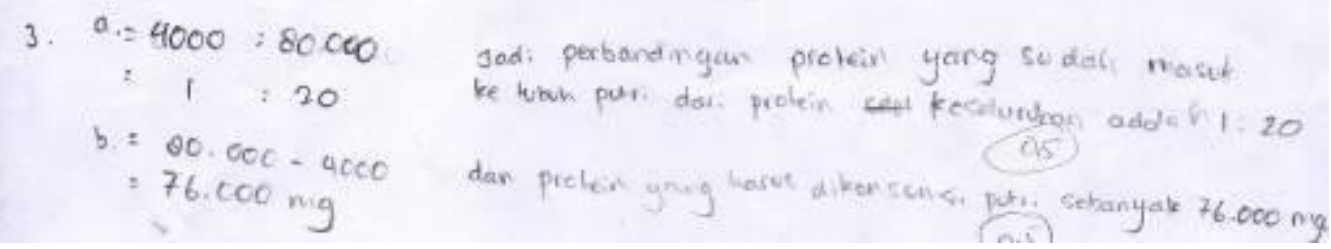

Figure 8. An Answer of Number 3 by One of The Male Students

Based on figure 8 , in completing the problem, the students compare the amount of protein that enters Putri's body with her daily protein needs. The students mentioned that the amount of protein that had entered Putri's body was $4000 \mathrm{mg}$ or half of $8000 \mathrm{mg}$ of protein contained in the milk box. Whereas in the nutritional information $8 \mathrm{~g}$ protein is the amount for one serving size, and for one box of milk it is as much as 4 serving sizes. So, the actual amount is half of 4 times 8 gr which is $16 \mathrm{gr}$.

This error can occur due to the lack of accuracy of the student when reading the questions. Another error that can be caused by a lack of accuracy when reading the questions is an operation error. Errors in operations were carried out by 7 male students, and were carried out by 2 female students. 


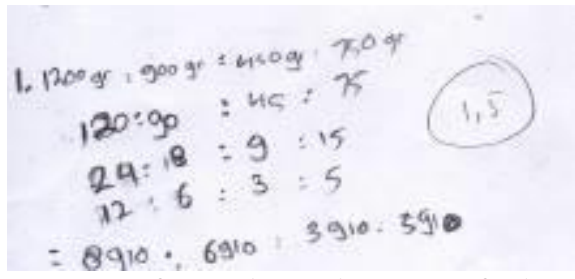

Figure 9. An Answer of Number 1 by One of The Male Students

One of the mistakes in the process made by the students at number 1 is that they made a calculation error in comparing grades as seen in figure 9. Reading errors and process errors can be caused by a lack of accuracy. Both of these errors become mistakes which are also dominated by male after writing down the answers. This is because female is more thorough than men. Kuretetzkii's opinion (Novitasari, 2017) states that female are superior in thoroughness, exactness, accuracy, and carefully thought out thinking.

The next type of error is the transformation error. Errors of transformation are further errors of misunderstanding, because when the students misunderstand a problem it will make mistakes in transforming information during the process. As with misunderstanding, the mistakes of transformation are mostly done by female students.

$$
\text { 5) } \begin{aligned}
\frac{10}{4} & =\frac{y}{5}=\frac{10}{4} \times \frac{5}{x} \\
4 \times 5 & =10 \times y \\
20 & =10=\frac{20}{10}=2
\end{aligned}
$$

Figure 10. An Answer of Number 5 by One of The Female Students

Figure 10 shows that the subject made a wrong mistake in transforming information on the formula, besides that the students were wrong in calculating operations. When interviewing the students claimed to know that the problem was using the concept of inverse proportion but the subject was confused when solving the problem of inverse proportion, it confirmed that students did not understand the concept well. Wati, Erna Hartika, Murtiyasa (2016) states that one of the causes of transformation errors was the lack of understanding of students' concepts in related problems. 


\section{9)

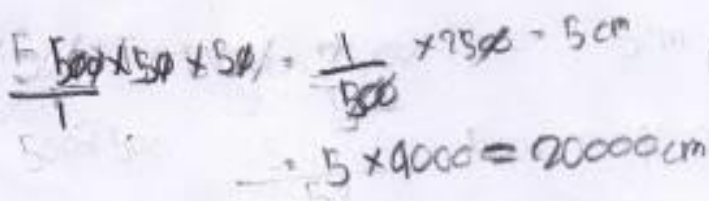

Figure 11. An Answer of Number 4 by One of The Male Students.

Transformation errors are also made by male students in question number 4 . The male students incorrectly transform information into scale formulas as seen in figure 11 . So, the calculation results obtained are also wrong. Transformation mistakes made by students when using the formula to find the actual distance. But the placement of the scale is wrong so that it produces the wrong answer as well. This shows that the subject did not understand the concept of direct proportion on the scale. Even though the concept of direct proportion was the subject before studying the concept of scale. This is consistent with the opinion of Saepudin, Prillangga, \& Zanthy (2019) which states that mathematics is the basis of an invention.

Although there are male students who make the mistakes of transformation, there are slightly more female students who make these mistakes. This can also show that female's ability to understand the problems in questions and use concepts who related to these questions is still lacking. This is in line with nafi'an (Yuberta, Setiawati, \& Kurnia, 2019) which states that male students are superior in reasoning and have better mathematical abilities than female students. The difference that is not too large can be caused by the good reasoning of female because it is influenced by accuracy and precision better than men. So the gap between men and women is not too large. As a result of Salmina \& Nisa's (2018) research which states the mathematical reasoning ability of female students is superior to the mathematical reasoning ability of male students. This is because the majority of male students tend to be less careful and less thorough.

\section{CONCLUSION}

Based on the finding, it can be concluded that there are differences between male and female students when working on ratio and proportion concept questions based on the mistakes they make. The most mistake was made by students in ratio and proportion concept are mistakes in the process of writing answers that are not complete information and answer conclusions. The mistakes in writing answers become the most mistakes made by male students. It is caused by male students tend to be simpler in solving problems. While the most 
mistakes made by female is related to understanding aspect. This is because female tend to use logic in understanding the mathematical problems presented in the problem. To be able to reduce these errors, learning can be done according to the needs of both male and female students fairly. So hopefully students' understanding of the concept of ratio and proportion will increase.

\section{REFERENCES}

Amalia, S. R. (2017). Analisis Kesalahan Berdasarkan Prosedur Newman Dalam Menyelesaikan Soal Cerita Ditinjau Dari Gaya Kognitif Mahasiswa. Aksioma, 8(1), 17. https://doi.org/10.26877/aks.v8i1.1505

Apriady, T., Yanis, A., \& Yulistini, Y. (2016). Prevalensi Ansietas Menjelang Ujian Tulis pada Mahasiswa Kedokteran FK Unand Tahap Akademik. Jurnal Kesehatan Andalas, 5(3), 666-670. https://doi.org/https://doi.org/10.25077/jka.v5i3.596

Dilla, S. C., Hidayat, W., \& Rohaeti, E. E. (2018). Faktor Gender dan Resiliensi dalam Pencapaian Kemampuan Berpikir Kreatif Matematis Siswa SMA. Journal of Medives : Journal of Mathematics Education IKIP Veteran Semarang, 2(1), 129. https://doi.org/10.31331/medives.v2i1.553

Hidayat, W. (2017). Adversity Quotient Dan Penalaran Kreatif Matematis Siswa Sma Dalam Pembelajaran Argument Driven Inquiry Pada Materi Turunan Fungsi. KALAMATIKA $\begin{array}{llll}\text { Jurnal Pendidikan } & \text { Matematika, } & 2(1), & 15 .\end{array}$ https://doi.org/10.22236/kalamatika.vol2no1.2017pp15-28

Ishak, S., \& Irmayanti. (2018). Perbandingan Kemampuan Menyelesaikan Masalah Matematika Pada Peserta Didik Laki-Laki Dan Perempuan Kelas VIII A SMP Negeri 4 Mamuju. Jurnal Pendidikan PEPATUDZU Media Pendidikan Dan Sosial Kemasyarakatan, 14(2), 172. https://doi.org/http://dx.doi.org/10.35329/fkip.v14i2.201

Kholishoh, F. nukma nur, Pramudya, I., \& Kurniawati, I. (2017). Analisis Kesalahan Dalam Menyelesaikan Soal Cerita Dengan Fong's Schematic Model For Error Analysis Pada Materi Volume Prisma Dan Limas Ditinjau Dari Gender Siswa Kelas VIII E SMP Negeri 1 Kartasura Tahun Ajaran 2015/2016. Jurnal Pendidikan Matematika Dan 
Matematika SOLUSI, 1(1), 16-35. Retrieved from http://www.jurnal.fkip.uns.ac.id/index.php/matematika/article/view/11201

Novitasari, D. (2017). Analisis Kreativitas Siswa Dalam Pemecahan Masalah Visual Spasial Dan Logis Matematis Ditinjau Dari Gender. Media Pendidikan Matematika, 5(2), 75. https://doi.org/10.33394/mpm.v5i2.1837

Novtiar, C., \& Aripin, U. (2017). Meningkatkan Kemampuan Berpikir Kritis Matematis Dan Kepercayaan Diri Siswa Smp Melalui Pendekatan Open Ended. Prisma, 6(2), 119-131. https://doi.org/10.35194/jp.v6i2.122

Nur, A. S., \& Palobo, M. (2018). Profil Kemampuan Pemecahan Masalah Matematika Siswa Ditinjau dari Perbedaan Gaya Kognitif dan Gender. Kreano, Jurnal Matematika Kreatif-Inovatif, $9(2), \quad$ 139-148. https://doi.org/http://dx.doi.org/10.15294/kreano.v9i2.15067

Purnawati, R., Paidi, \& Hidayati, S. (2016). Identifikasi Langgam Belajar Siswa SMA Negeri di Kota Yogyakarta dalam Mempelajari Biologi Menggunakan LSI Kolb. Jurnal Pendidikan Biologi, 5(3), 56-62. Retrieved from http://journal.student.uny.ac.id/ojs/ojs/index.php/pbio/article/view/4524

Purwanto, wahyu ridlo, Sukestiyarno, Y., \& Junaedi, I. (2019). Proses Berpikir Siswa dalam Memecahkan Masalah Matematika Ditinjau dari perspektif gender. Seminar Nasional Pascasarjana 2019, 894-900. Retrieved from https://proceeding.unnes.ac.id/index.php/snpasca/article/view/390

Rahmasantika, D., \& Prahmana, R. C. I. (2019). Desain Pembelajaran Perbandingan Senilai Menggunakan Guided Inquiry. Journal of Honai Math, 1(1), 1-13.

Resilona, S. F., Hidayat, W., \& Hendriana, H. (2018). Peningkatan Kemampuan Pemecahan Masalah Melalui Pembelajaran Berbasis Masalah Siswa SMP. JPMI (Jurnal Pembelajaran Matematika Inovatif), 1(4), 487-492. https://doi.org/10.32665/james.v1ioctober.42 
Respati, R., \& Gusrayani, D. (2016). Pengaruh Pendekatan Problem-Based Learning (Pbl) Terhadap Kemampuan Pemahaman Matematis Dan Komunikasi Matematis Siswa Pada Materi Skala Dan Perbandingan. Pengaruh Pendekatan Problem-Based Learning (PBL) Terhadap Kemampuan Pemahaman Matematis Dan Komunikasi Matematis Siswa Pada Materi Skala Dan Perbandingan, 1(1), 171-180. https://doi.org/10.23819/pi.v1i1.2951

Saepudin, F., Prillangga, P., \& Zanthy, L. S. (2019). Analisis Kemampuan Komunikasi Matematis Siswa SMP Kelas VIII. Journal On Education, 1(4), 625-633.

Salmina, M., \& Nisa, S. khairun. (2018). Kemampuan Penalaran Matematis Siswa Berdasarkan Gender Pada Materi Geometri. Numeracy, 5(1), 41-48. Retrieved from https://ejournal.bbg.ac.id/numeracy/article/download/304/274

Sari, A. R., \& Aripin, U. (2018). Analisis Kesalahan Siswa Dalam Menyelesaikan Soal Cerita Bangun Datar Segiempat Ditinjau Dari Kemampuan Pemecahan Masalah Matematik Untuk Siswa Kelas Vii. JPMI (Jurnal Pembelajaran Matematika Inovatif), 1(6), 1135. https://doi.org/10.22460/jpmi.v1i6.p1135-1142

Utari, R. S., Ilma, R., Putri, I., \& Hartono, Y. (2015). Konteks Kebudayaan Palembang untuk Mendukung Kemampuan Bernalar Siswa SMP pada Materi Perbandingan. 2(2), 2737. https://doi.org/10.24815/dm.v2i2.2847

Wati, E. H., \& Murtiyasa, B. (2016). Kesalahan Siswa SMP dalam Menyelesaikan Soal Matematika Berbasis PISA Pada Konten Change and Relationship. Konferensi Nasional Penelitian Matematika Dan Pembelajarannya (KNPMP I), 199-209. Retrieved from https://publikasiilmiah.ums.ac.id/bitstream/handle/11617/6959/21_77_Makalah Rev Erna Hartika Wati.pdf;sequence=1

Yazidah, N. I. (2017). Analisis Kesalahan Menyelesaikan Soal Pembuktian Geometri Euclid Ditinjau dari Gender pada Mahasiswa Ikip Budi Utomo Malang. KALAMATIKA Jurnal Pendidikan Matematika, 2(1), 71-80. https://doi.org/10.22236/kalamatika.vol2no1.2017pp71-80 
Yuberta, K. R., Setiawati, W., \& Kurnia, L. (2019). Pengaruh Math Anxiety Terhadap Kemampuan Pemahaman Konsep Matematis Siswa. AGENDA: Jurnal Analisis Gender Dan Agama, 2(1), 81-87. Retrieved from http://ecampus.iainbatusangkar.ac.id/ojs/index.php/agenda/article/view/1995

Zannati, G. N., Fitrianna, A. Y., \& Rohaeti, E. E. (2018). Pengaruh Kemandirian Belajar Terhadap Kemampuan Penalaran Matematis Siswa pada Materi Perbandingan. Jurnal Pendidikan Matematika Inovatif, 1(2), 107-112. https://doi.org/10.22460/jpmi.v1i2.93218 
118 KALAMATIKA, Volume 5, No. 2, November 2020, pages 103-118 